\title{
Comparative Analysis of Lineaments of the Western Portion of the State of Roraima from Aeromagnetometric Data, SRTM and R99 / SAR.
}

Phaulla Oliveira, Solange dos Santos Costa and Jorge Alberto Lopes da Costa.

Copyright 2019, SBGf - Sociedade Brasileira de Geofísica

This paper was prepared for presentation during the $16^{\text {th }}$ International Congress of the Brazilian Geophysical Society held in Rio de Janeiro, Brazil, 19-22 August 2019.

Contents of this paper were reviewed by the Technical Committee of the $16^{\text {th }}$ International Congress of the Brazilian Geophysical Society and do not necessarily represent any position of the SBGf, its officers or members. Electronic reproduction or storage of any part of this paper for commercial purposes without the written consent of the Brazilian Geophysical Society is prohibited.

\section{Abstract}

This research was developed in the western portion of Roraima, Sheet NA.20-V-D, inserted in the Domain Parima-Uraricoera, aiming to perform a comparative analysis of lineaments between different inputs. The methodological basis was the elaboration of a shading map $\left(60^{\circ}\right)$ from the SRTM data, image of the First Vertical Derivative with synthetic lighting of $45^{\circ}$ and $135^{\circ}$ and image R99 / SAR, with mosaic form and synthetic shading at $45^{\circ}$. For the comparative analysis, lineaments were extracted automatically in the Geomatics $\mathrm{PCl}$ software (trial version), taking into account parameters such as spatial resolution, frequency, lineaments statistics and spatial distribution. The rosette diagrams were generated in the Rock Works 17 software, and Arcgis 10.2 was used for the statistical analysis of the data. Based on the processing it was possible to observe from the First Derivative that the lineaments have a longer length, but a smaller amount, when compared to the SRTM and R99 / SAR data, where the lineaments are more fragmented and of shorter length. Based on the rosette diagram, it was possible to notice a concordance of the lineaments in the three inputs (NW-SE and subordinately E-W) with those of the Cauarane-Coeroeni Belt.

\section{Introduction}

The use of Remote Sensing in the researches related to the geological and tectonostructural characterization of areas with scarce mapping, as western portion of Roraima, becomes extremely important for the contribution of geological knowledge of the region (Costa ,1999). The processing and integration of aerogeophysical data of medium spatial resolution with RADAR images (Radio Detection and Ranging) and SRTM data (Shuttle Radar Topography Mission) allow the identification and analysis of the lineaments.

According to O'Leary et al. (1976), lineament is a rectilinear or little curved feature which can be identified in the image by the color intensity, and are presented in the simple or compound form of which the parts form a linear plot representing the shape of the topography on the surface. They may have natural or anthropogenic genesis. In relation to natural genesis, they may be the result of geomorphology, geological structures (faults, fractures, mineralized zones, lithological contacts) and drainage systems.

In Roraima, the western portion of the state has fewer geological studies than the southern, eastern and northern portions, this is due to the presence of dense vegetation cover and the fact that it is inserted in the Yanomami Indigenous Land, thus limiting the access (Costa, 1999). The study area is located in the ParimaUraricoera Domain, the western portion of Roraima, bordering Venezuela (Figure 1), corresponding to Sheet NA.20-V-D. Fraga et al. (2008), defined a tectonostratigraphic model based on a metamorphic highgrade belt related to a megastructure, known as the "Cauarane-Coeroeni Belt", subdivided into five domains, among them the Parima-Urariquera.

Considering the availability of aerogeophysical data, Radar images, SRTM data and pre-existing geological information, this research was developed with the purpose of characterizing the geological features of the Parima-Uraricoera Domain, west portion of Roraima (Folha NA.20-V-D), using a combination of aeromagnetic signatures, textural analysis and the Digital Elevation Model (MDE), that is, to correlate the textural responses of Radar images with aeromagnetic responses, MDE and available information. geological

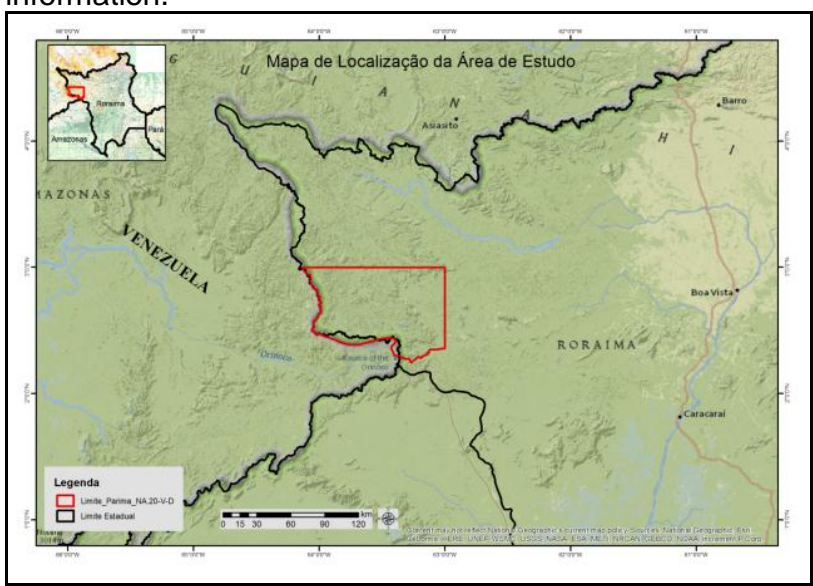

Figure 1. Location of the study area, Parima-Uraricoera Domain in red color (Sheet NA.20-V-D).

\section{Theory and Method}

The aeromagnetic data used in this project were made available by the Geological Service of Brazil, based on the Aerogeophysical Surveys of the Amazon. The information corresponds to Project 1058 - Mineral Province Minima Parima-Uraricoera, the aeromagnetic data have $0.5 \mathrm{~km}$ flight lines (LV) and $10 \mathrm{~km}$ control lines, 
respectively with NS and EW orientation and with flight height of $100 \mathrm{~m}$ ( CPRM, 2001). The radar data used are from the Amazon Protection System (SIPAM) sensor R99/SAR, with spatial resolution of 6 meters and 8 bits.

In order to discriminate the geological features of the study area, data relating to the SRTM mission elevation model with spatial resolution of $30 \mathrm{~m}$ were used free of charge. The selected image was obtained from the SRTM image catalog on the United States Geological Survey website (USGS). Available at the following website address: https://earthexplorer.usgs.gov/. The vector data (shapefiles) that were used are made available by the CPRM website, through GEOSGB: http://geosgb.cprm.gov.br/", with geoinformation content, such as: description of outcrops, geological map and structural geology.

For this research, images were processed using the tools provided by the ArcGis 10.4.1, ENVI 5.3, Oasis Montaj 6.3, Geomatics PCl (trial version) and Rock Works17 programs. The steps of the methodology are summarized in figure 2, and detailed in the following items:

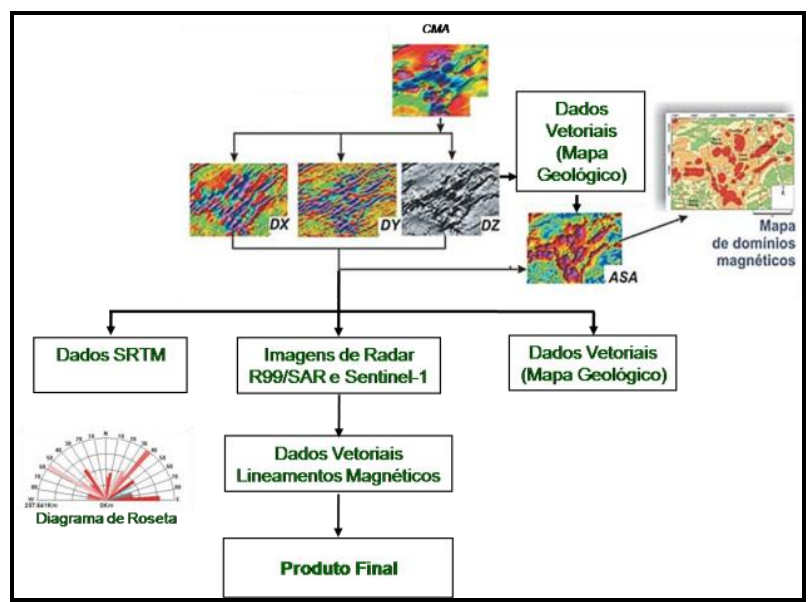

Figure 2. Stages of methodological procedures.

Aeromagnetic data were processed using Oasis Montaj 6.3 software. The raw data were imported and interpolated by the Minimum Curvature method, which smooths the surface based on values close to the threshold data (KECKLER, 1994). Considering that in the Parima-Uraricoera Project the spacing between the flight lines was $500 \mathrm{~m}$, a value of $1 / 4$, or $62.5 \mathrm{~m}$, was chosen, rounded up to $63 \mathrm{~m}$, which provided satisfactory results, (VASCONCELLOS et al., 1990).

After the definition of the cell size, the image of the Residual Magnetic Field (MAGR) was generated, from which the Analytical Signal Amplitude (ASA) filter was applied, which is directly related to the magnitude of the magnetization, Thus, the delimitation of the magnetic sources (MILLIGAN e GUNN (1997), BLUM (1999)). In addition to the ASA filter, the First Derivative filter was used to emphasize the structural features such as: shear zones, faults, fractures and folds (LUIZ and SILVA, 1995).

From the MDE obtained from the SRTM the shading map of the $60^{\circ}$ relief was generated, Hillshade tool available in ArcGis 10.4 , with the parameter altitude, or factor $Z$, for latitude of the study region equal to 0.00000898 .
The available images of the R99 / SAR, L-band, fourpolarization sensor were: $\mathrm{HH}, \mathrm{VV}, \mathrm{VH}$ and $\mathrm{HV}$, were mosaicated and applied to the color composition technique and a synthetic shading at $45^{\circ}$, through which it was possible to perform a better visual interpretation of the structural features of the area investigated. Because the R99 / SAR images did not cover the entire area related to the NA.20-D-V chart, it was necessary to trim the area for analysis. This area was defined from the texture contrast, linked to both topography and vegetation, as well as to the lithology of the region.

For the geological interpretation of the region, the extraction of information regarding the structural lineaments of SRTM, aeromagnetometric and R99 / SAR data was performed. The extraction of the lineaments was performed automatically through the LINE algorithm, which is part of the FOCUS module of the PCI Geomatics Software. The process consists of an image scanning based on global or user-defined parameters, in which it transforms linear features contained in the raster image into a segment in vector form.

For the comparative analysis of the inputs, a density map was generated to analyze the spatiality and to identify the concentrations of the lineaments generated, through the Line Density tool of the program ArcGis 10.4, through which the calculation of each linear shape per pixel is performed and its density to identify the regions with the highest concentration of the lineaments. Then, the statistics of the guidelines were obtained, obtaining data on the amount of lineaments, length (in meters) maximum, minimum and the average of the lineaments identified in the study area for later comparison between the inputs, for which the program was used ArcGis 10.4.

Subsequently, rosette diagrams were generated for the interpretation of the linear features obtained. The rosette diagram, being circular or semicircular, allows an analysis based on the total number of lineaments in several directions, as well as the frequency and accumulated length, this procedure was performed in Rock Works 17 software. According to Reeves et al. (1983) this type of diagram allows to identify the dominant structural directions and their variations in the terrain.

\section{Results}

The image of the Residual Magnetic Field (MAGR) in pseudocor generated from the Parima-Uraricoera project area and highlighted in the red polygon of the study area, presents magnetic field values that are between - 2265,1 $\mathrm{nT}$ and $1637,7 \mathrm{nT}$, the magenta color represents the maximum values and the blue color represents the minimum values (Figure 3 ). It is noted in this image that the magnetic anomalies present the indication of numerous elongated structural features, apparently with preferred directions NW-SE, ENE-WSW and NE-SW. The observed anomalies of the MAGR image (Figure 3) were better defined from the Amplitude of the Analytical Signal (Figure 4). For the First Vertical Derivative (Figure 5) the synthetic shading of $45^{\circ}$ and $135^{\circ}$ was applied in order to highlight the structures and lineaments present in the area. 


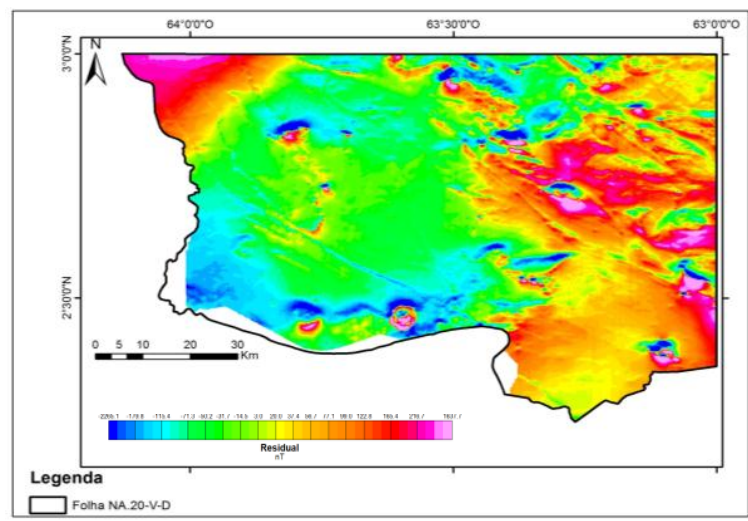

Figure 3. Residual Anomalous Magnetic Field (MAGR), obtained from the Minimum Curvature method.

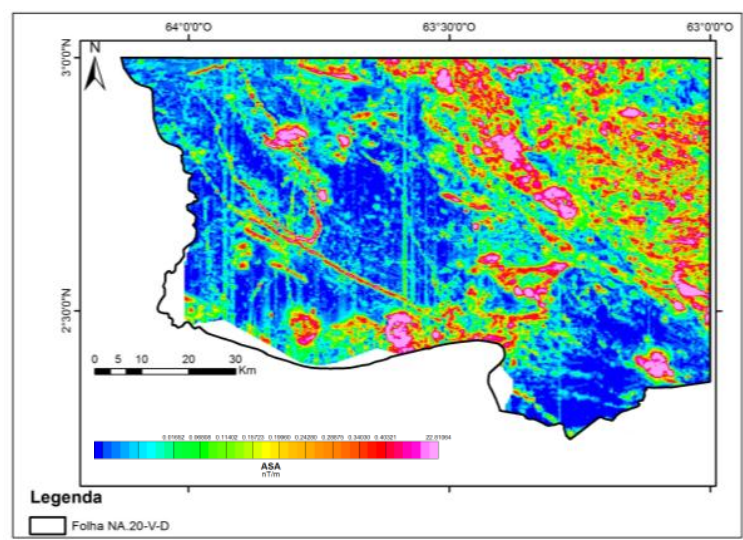

Figure 4. Image of the Amplitude of the Analytical Signal (ASA).

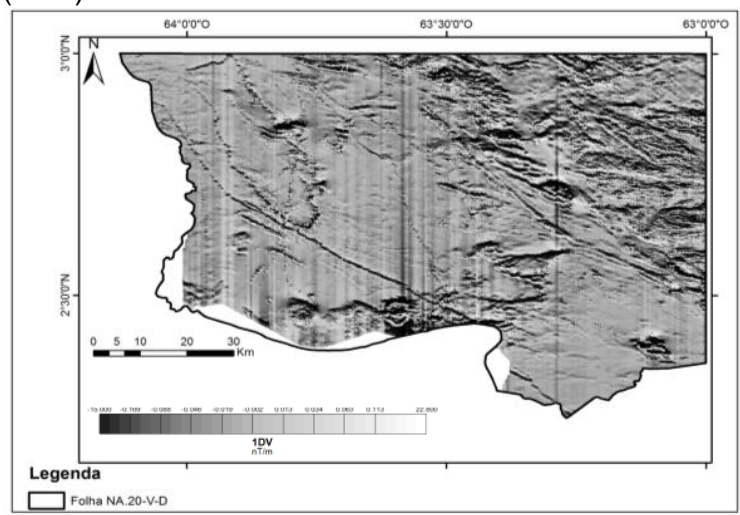

Figure 5. Image of the First Vertical Derivative.

With the processing of the images of the First Vertical Derivative, the lineaments were extracted automatically, as shown in Figure 6, and the same extraction procedure was performed for the SRTM images using the shaded relief, according to Figure 7.

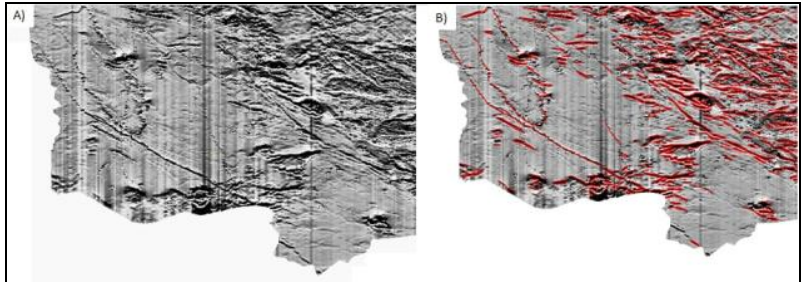

Figure 6. In A) Image of the first derivative; B) Linearizations obtained from the automatic extraction.

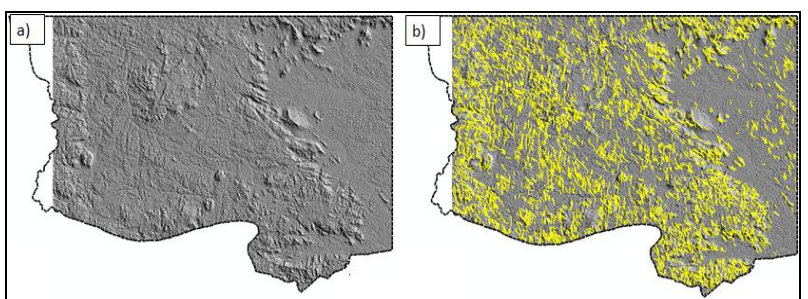

Figure 7. In a) Image of the shaded relief; b) Linearizations obtained from the automatic extraction.

After the extraction, a comparison was made between the guidelines of the two inputs, considering the rosette diagrams (Figure 8 (C) e (D)) and the amounts of lineaments, maximum, minimum and average lengths in meters (Figure $8(E)$ e $(F)$ ).

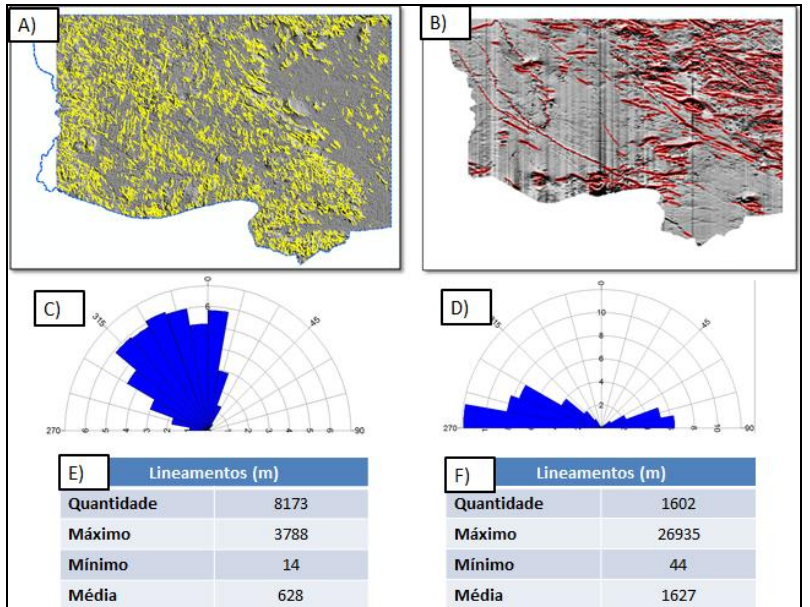

Figure 8. In A) Image of the SRTM (Shading Map) superimposed, the lineaments extracted automatically; B) First Vertical Derivative with the overlap of automatically extracted lineaments; C) SRTM Rosette Diagram $\left(60^{\circ}\right.$ inclination); D) Rosette Diagram First Derivative (45을 $135^{\circ}$ of slope); E) and F) Tables containing the approximate amount and values of the maximum, minimum and average length of the lineaments.

Taking into account that SRTM data have $30 \mathrm{~m}$ spatial resolution and correspond to surface data and aeromagnetometry data have $63 \mathrm{~m}$ of spatial resolution and are subsurface, in comparison between the two inputs are verified in the image of the SRTM 8.173 lineaments identified according to Figure $8 \mathrm{~A}, \mathrm{C}$ and $\mathrm{E}$, and in the image of the First Vertical Derivative the value was 1,602 lineaments (Figure $18 \mathrm{~B}, \mathrm{D}$ and F). The Rosette Diagram obtained from the lineages extracted from SRTM data (Figure 18C) indicates lineaments with 
preferred directions for NW-SE, this direction coincides with the preferred direction of the Cauarane-Coroeni Belt. The Rosette Diagram obtained from the First Vertical Derivative lineaments show a preferential E-W direction, probably associated with structures with conjugated direction according to Reis et al. (2003, 2006).

The largest lineage identified in the SRTM image is approximately $3,788 \mathrm{~m}$ in length, while in the First Vertical Derivative, the largest lineage measured about $26,935 \mathrm{~m}$ in length, indicating that not all the lineaments, visualized in subsurface, were identified in surface, probably due to the natural process of erosion, or discontinuity of the same, not reaching the surface. As for the higher number of surface lineaments, they are probably related to the topography of the area and the higher spatial resolution of the SRTM altimetry data when compared to the First Vertical Derived image.

Considering the absence of segments covering the entire study area, an area representative of the area was selected for the analysis of the structural features, according to Figure 9 (a), in order to perform a comparison between all the available inputs containing the image of the First Vertical Derivative (Figure 9 (b)), R99 / SAR image (Figure 9 (c)) and altimetric SRTM data (Figure $9(\mathrm{~d})$ ), and the results obtained are compiled in Table 5 .

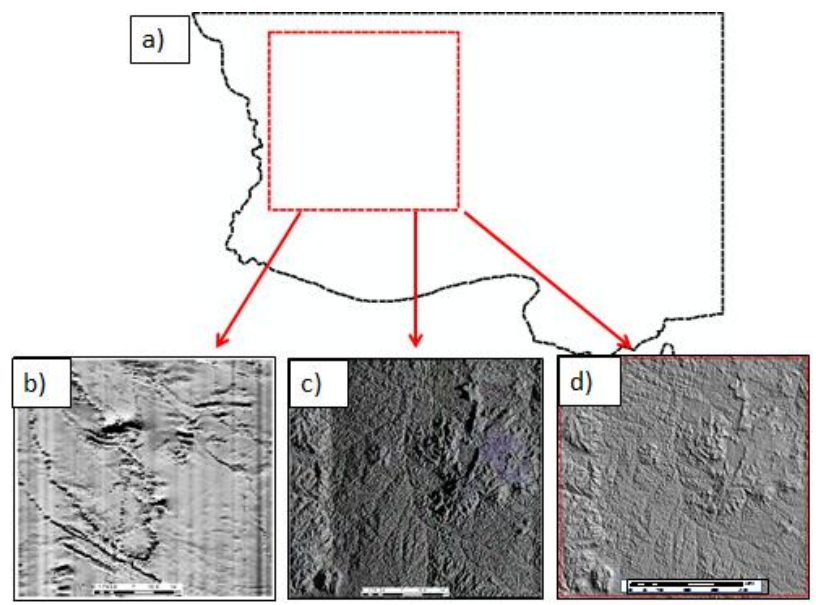

Figure 9. In a) Delimitation of the Parima Domain (in black), and in red, the area selected as representative. The images (b), (c) and (d) indicate the cut-outs made on the First Vertical Derivative, R99 / SAR and SRTM data, respectively, for further processing. image R99 / SAR and altimetric SRTM data, and the results obtained are compiled in Table 5.
Table 1. Comparisons between the SRTM, R99 / SAR and aeromagnetometry inputs after the processing of these.

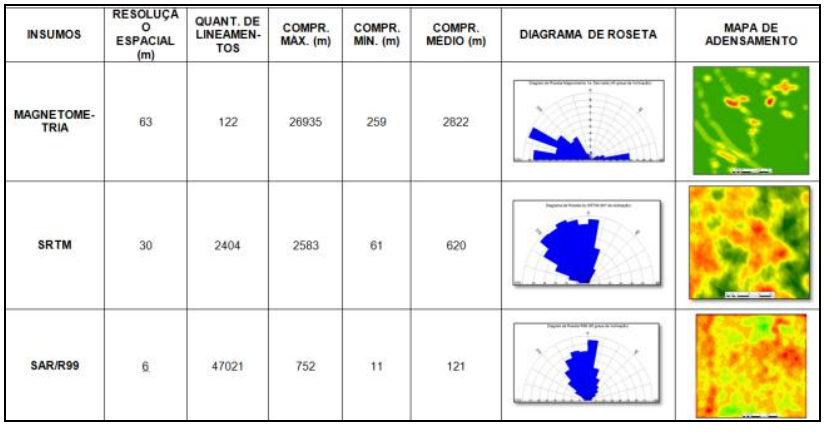

When analyzing Table 5 , it is observed that the values obtained from the image R99 / SAR with $6 \mathrm{~m}$ of spatial resolution, are the ones that have the most amount of lineaments with approximately 47,000, but have shorter line lengths (maximum of $750 \mathrm{~m}$ and minimum of $11 \mathrm{~m}$ ), the rosette demonstrates preferred N-S and subordinate NW-SE lineaments. The NW-SE lineaments agree with the regional targeting, as mentioned in Table 1 and N-S and higher density in the northeast and northwest regions of the image.

The values obtained from the SRTM data demonstrate about 2,400 lineaments identified in the image, with a maximum of $2,500 \mathrm{~m}$ and a minimum of $61 \mathrm{~m}$ in length. The rosette diagram indicates preferred direction from NW-SE to N-S and thickening of the lineaments in the central and northwestern portions of the image.

From the First Vertical Derivative, the smallest amount of lineaments has been identified, about 120, but they point to the largest lengths, with approximately 27,000 meters, and a minimum length of approximately $260 \mathrm{~m}$. The rosette diagram indicates preferred W-E direction to NWSE and density in the central portions of the image.

In the densification maps the difference between the number of lineaments is greatly enhanced, being proportional to the surface or subsurface, where in red are the largest concentrations of lineaments and in green the lowest concentrations of lineaments.

\section{Conclusions}

Based on the First Vertical Derivative, it was possible to extract the lineaments and perform the evaluation of them, this input proved to be effective since it covers the entire study area and can be compared with other data. From the identified lineaments, it was possible to analyze the difference that exists, both in relation to length and in relation to the amount of lineaments that were identified in the surface and subsurface. The rosette diagram indicates the preferred direction of the E-W and NW-SE lineaments bound to the Cauarane-Coeroeni Belt.

The R99 / SAR images had gaps in the available segments, so only a portion of the image was used for processing, analysis and correlation with the other inputs. However, the data were satisfactory for the extraction of the lineaments and their evaluation. The rosette diagram indicated preferred directions of N-S and NW-SE. It is 
suggested a re-imaging of the area by the R99 / SAR sensor, to fill in the gaps identified in Sheet NA.20-V-D. The SRTM data is enabled for the extraction of the lineaments in a satisfactory way. The rosette diagram presented preferred directions of N-S and NW-SE.

Based on the information obtained through the processing and the comparative analysis, it was possible to observe the distinctions in the verified inputs, as the higher the spatial resolution and the location in relation to the surface of the analyzed input, the greater the number of identified lineaments, however, the smaller the extension of the same. the greater the spatial resolution and location in relation to depth the smaller the number of lineaments and the greater the extension of the same. In short, the data processed allowed the analysis of the lineaments, quantify them and measure them, as well as verify their spatialization and preferential directions.

The identified lineaments agree with the preferential trend of the NW-SE region and subordinately E-W, ascribed by the Cauarane-Coroeni Belt, as described by Holanda et. to (2014).

\section{Acknowledgments}

To the Regional Center of Manaus of the Amazon Protection System - SIPAM, for offering all the necessary structure for the development of this research through the Program of Support of Initiation to Research - PAIC and the Foundation of Support to Research of the State of Amazonas for the financing of the scholarship study and the opportunity given to perform this work. Thanks in particular to Pamela Judith Ribeiro for the help with this article.

\section{References}

BLUM M.L.B. Processamento e Interpretação de Dados de Geofísica Aérea no Brasil Central e sua Aplicação a Geologia Regional e a Prospecção Mineral. Tese de Doutorado, Instituto de Geociências, Universidade de Brasılia, 229 p,1999

CPRM. Projeto aerogeofísico Província Mineral ParimaUraricoera. Relatório final do levantamento e processamento dos dados magnetométricos e gamaespectrométricos. Brasília: CPRM, 2001

CONCEIÇÃO, R. A. C.; SILVA, A. Q. Extração automática de lineamentos utilizando imagens SRTM, Landsat ETM+ e ALOS PALSAR na região de Nobres, MT. In: SIMPÓSIO BRASILEIRO DE SENSORIAMENTO REMOTO, 16. (SBSR), 2013, Foz do Iguaçu. Anais... São José dos Campos: INPE, 2013. p. 3688-3695.

COSTA, S.S. Avaliação do conteúdo geológico em produtos de sensoriamento remoto da porção oeste do Estado de Roraima (Folha NA. 20-V-D). Instituto de Geociências, Universidade Estadual de Campinas, Campinas, Dissertação de Mestrado, 83 p. 1999.

FRAGA L.M.B., REIS N.J., DALL'AGNOL R., ARMSTRONG R. 2008. Cauarane-Coeroeni Belt - The tectonic southern limit of the preserved Rhyacian crustal domain in the Guyana Sheild, northern Amazonian craton. In: Int. Geol. Cong., 33, Oslo, Noruega. CD-Rom.

HOLANDA, J. L. da R.; MARMOS, J. L.; MAIA, M. A. M. Geodiversidade do estado de Roraima. Manaus: CPRM, 2014. 212 p. Programa Geologia do Brasil. Levantamento da Geodiversidade.

O'LEARY, D.W.; FRIEDMAN, J.D.; POHN, H. A. Lineament, linear, lineation: some proposed new standards for old terms.Geological Society of America Bulletin, v. 87, p. 1463-1469, 1976.

LUIZ JG; SILVA LMC. 1995. Geofísica de Prospecção. Belém, UFPA, Cejup, $311 \mathrm{p}$.

MILLIGAN P.R. ; GUNN P.J. 1997. Enhancement and presentation of airborne geophysical data. AGSO JournalofAustralianGeology\&Geophysics, 17(2): 63-75.

O'LEARY, D. W.; FRIEDMAN, J. D.; POHN, H. A. Lineament, linear, lineation: some proposed new standards for old terms. GSA Bulletin, v. 87, p. 14631469, 1976.

REIS N.J., FRAGA L.M.B., FARIA M.S.G., ALMEIDA M.E. 2003. Geologia do Estado de Roraima, Brasil. Géologie de la France, $\mathrm{n}$ ㅇ 2-3-4, 121-134.

REEVES, M., PINE,L., NEILANDS, J. B. e BULLOWS, A. (1983). Absence of siderophore activity in Legionella sp. grown in iron deficient media. Journal of Bacteriology 154, 324-329.

VASCONCELOS, R.M.; METELO, M.S.; MOTA, A.C. \& GOMES, R.D. 1990. Geofísica em Levantamentos Geológicos. Rio De Janeiro, Digeof-Cprm. 